\title{
Harmonia axyridis in Chile: a new threat
}

\author{
Audrey Grez ${ }^{1}$, Tania Zaviezo ${ }^{2}$, Guillermo González ${ }^{3}$, and Sergio Rothmann ${ }^{4}$ \\ ${ }^{1}$ Facultad de Ciencias Veterinarias y Pecuarias, Universidad de Chile, Casilla 2, Correo 15, la Granja, \\ Santiago, Chile. \\ ${ }^{2}$ Facultad de Agronomía e Ingeniería Forestal, Pontificia Universidad Católica de Chile, Casilla 306-22, \\ Santiago, Chile. \\ ${ }^{3}$ Nocedal 6455, La Reina, Santiago, Chile. \\ ${ }^{4}$ Laboratorio de Entomología, Subdepto. Laboratorios y Estación Cuarentenaria Agrícola, Servicio Agrícola \\ y Ganadero (SAG), Ruta 68, Km. 22, Santiago, Chile.
}

\begin{abstract}
A. Grez, T. Zaviezo, G. González, and S. Rothmann. 2010. Harmonia axyridis in Chile: a new threat. Cien. Inv. Agr. 37(3): 145-149. In this work, we document the presence of Harmonia axyridis in Chile, an invasive coccinellid species that has had negative effects in other regions of the world, such as: impacts on non-target arthropods, invasions of houses and fruit damage. This species has been found in the last three years in the Metropolitan and Valparaíso regions, in crops, pine plantations and inside houses. We warn about the consequences of the introduction of this species to Chile and claim to take actions to avoid its spread in the country.
\end{abstract}

Key words: biological invasions, Coccinellidae, Harmonia axyridis, Harlequin lady beetle, Asian lady beetle.

\section{Introduction}

The multicolored Asian lady beetle or harlequin ladybird, Harmonia axyridis (Pallas) (Coleoptera: Coccinellidae), is a generalist predator native to Asia that has been imported to various countries in North and South America and Europe, for the biological control of aphids and other insects (Koch, 2003; Saini, 2004; Koch et al., 2006). Nevertheless, after its introduction to new areas, the insect has spread rapidly and increased in abundance, becoming a successful invader and considered one of the most risky exotic natural enemy used in inundative biological control (van Lenteren et al., 2003; Roy and Wajnberg, 2008). Koch et al. (2006) reviewed its invasion history in the western hemisphere.

Received January 15, 2010. Accepted January 30, 2010. Corresponding author: agrez@uchile.cl
In these new areas, several adverse effects have been reported such as: impacts on non-target arthropods, particularly the apparent displacement of native coccinellid species (Cottrell and Yeargan, 1998; Burgio et al., 2002; Lucas et al., 2002; Brown, 2003, Koch and Galvan, 2008); invasions of houses where they aggregate when seeking overwintering sites, causing cosmetic damage and, occasionally, biting humans and causing allergic reactions (Huelsman et al., 2002); indirect damage on fruits where they aggregate, causing contamination and potentially direct damage by feeding on agriculture products (Hesler et al., 2004; Koch et al., 2004; Kovach, 2004; Koch and Galvan, 2008). The problems caused by this species seem to result from a number of ecological traits including generalist feeding habit, voracity and aggressiveness towards other predators through intra-guild 
predation and propensity to overwinter in buildings (van Lenteren et al., 2003; Pell et al., 2008). Harmonia axyridis is now widely regarded as an unwanted invasive alien species for which there are currently no control strategies (Kenis et al., 2008).

In South America, $H$. axyridis has been reported to be present in Argentina (Saini, 2004) and Brazil (Almeida and Silva, 2002), being intentionally introduced to Mendoza, Argentina, in the late 1990's, and later on found in Buenos Aires and in Curitiba, Brazil. Also, Silvie et al. (2007) have reported the presence of adults and larvae in cotton fields in Paraguay (Caaguazú, Itapúa and Cordillera), and in material from Perú (Tumbes and Lima) (G. González personal observation), where $H$. axyridis is frequently found, and is apparently established. The results of climate and habitat matching analyses comparing South America to Asia have suggested that much of South America may be suitable for establishment of $H$. axyridis (Koch et al., 2006), and therefore, other countries beside Argentina, Brazil, Paraguay and Perú may be soon incorporated to the distribution range of this species.

Up to now, $H$. axyridis has not been reported in the scientific literature to be established in Chile. In 1998 a flightless strain of H. axyridis was introduced from France to Chile, to be used as a biological control agent in greenhouses. It was released near La Cruz (Quillota Province, Valparaíso Region), but it was not subsequently found (F. Rodríguez, Instituto de Investigaciones Agropecuarias INIA, Chile, personal communication). In 2003, there were reports of the presence of large numbers of flying individuals associated with aphids in poplar trees (Populus sp.) near Los Andes (Los Andes Province, Valparaíso Region), but no new observations of these populations were reported in subsequent years (F. Rodríguez, Instituto de Investigaciones Agropecuarias INIA, Chile, personal communication). It is possible that these individuals represent accidental introductions from Argentina. In this study, we document new geographical areas and habitats where this species has been found in Chile, and highlight problems associated with the potential spread of this invasive species.
Collections reported here were made from May 2008 to August 2009, where H. axyridis was found accidentally while monitoring insects (Table 1); funnel traps are used by SAG (Servicio Agrícola y Ganadero) in their permanent surveillance program to detect forest pest introductions, and the sticky traps were used in a study to determine the effect of edge vegetation on coccinellid migration to alfalfa fields (Grez et al., 2010). After the acceptance of the manuscript, in fall 2010, a large number of new records took place and were added to Table 1. Specimens were identified by G. González and A. Grez and deposited in the collections of the Laboratory of Ecology, Faculty of Veterinary Sciences, University of Chile; Laboratorio de Entomología, Subdepto. Laboratorios y Estación Cuarentenaria Agrícola, SAG, and also in G. González private collection. Between 2008 and 2009, a total of 27 specimens -all adultswere found in these collections (Table 1), suggesting that $H$. axyridis was in a colonization phase. However, in 2010 (April - June), these numbers raised to 1128 individuals -including larvae, pupae and adults- which represent about 80 times more of what was found the previous two years (Table 1). Most $H$. axyridis $(99.7 \%)$ were collected from April to June, and the rest from July to September, but never in summer. Therefore, they probably are active when temperatures are mild. So far, this species has been collected only in central Chile, in locations near to the foothills of the Andes, close to Argentina. However, it is interesting to note the diversity of habitats where the specimens have been found, ranging from pine plantations, alfalfa fields and inside houses in the Santiago suburbs. This last finding is important because represents one of the main problems associated with this species, which is considered a direct nuisance to humans and as a household pest (Koch et al., 2006).

Biotic invasions are considered to be one of the most important mechanisms of global environmental change as well as a leading threat for worldwide biodiversity, after habitat destruction (Vitousek et al., 1996; Pimentel et al., 2000; Roy and Wajnberg, 2008). This is particularly true for Mediterranean ecosystems like Central Chile (Sala et al., 2000). Given the negative impacts of $H$. axyridis reported in 
other regions, and the considerable number of individuals collected in the last three years in Central Chile, we consider that it is important to prohibit intentional introduction of this species, and to take actions to monitor and limit the spread of the current populations of this invasive species in Chile.

\section{Acknowledgements}

We thank Constanza Torres, Allison Fernández and Elizabeth Gazzano for field collections of Harmonia axyridis. Also, thanks to Carolina Romero for providing some specimens for identification and Helen Roy and Robert Koch for helpful comments to the manuscript. Financial support was provided by FONDECYT 1070412 and FONDECYT 1100159.

Table 1. Details of locations, sampling methods, habitat, date, number of individuals and collectors of Harmonia axyridis in Chile.

\begin{tabular}{|c|c|c|c|c|}
\hline $\begin{array}{l}\text { Place (County, } \\
\text { Province, Region) }\end{array}$ & $\begin{array}{l}\text { Sampling method and } \\
\text { Habitat }\end{array}$ & Date & $\begin{array}{l}\mathrm{N}^{\mathrm{o}} \text { of } \\
\text { individuals }\end{array}$ & Collector \\
\hline $\begin{array}{l}\text { Pirque, Cordillera, } \\
\text { Metropolitan Region }\end{array}$ & Sticky trap in alfalfa & May 2008 & 1 & Constanza Torres $^{\mathrm{a}}$ \\
\hline $\begin{array}{l}\text { Llay Llay, San Felipe, } \\
\text { Valparaíso Region }\end{array}$ & $\begin{array}{l}\text { Funnel trap in Pinus } \\
\text { sp. }\end{array}$ & May 2008 & 12 & Álvaro Silva ${ }^{b}$ \\
\hline $\begin{array}{l}\text { San Felipe, San Felipe, } \\
\text { Valparaíso Region }\end{array}$ & $\begin{array}{l}\text { Funnel Trap in Pinus } \\
\text { radiata }\end{array}$ & September 2008 & 1 & $\mathrm{nn}$ \\
\hline $\begin{array}{l}\text { San Esteban, Los } \\
\text { Andes, Valparaíso } \\
\text { Region }\end{array}$ & $\begin{array}{l}\text { Funnel trap in Pinus } \\
\text { radiata }\end{array}$ & May 2009 & 9 & Iván Ahumada ${ }^{\mathrm{b}}$ \\
\hline $\begin{array}{l}\text { Los Andes, Los Andes, } \\
\text { Valparaíso Region }\end{array}$ & $\begin{array}{l}\text { Funnel trap in Pinus } \\
\text { radiata }\end{array}$ & May 2009 & 1 & Iván Ahumada ${ }^{b}$ \\
\hline $\begin{array}{l}\text { Huechuraba, Santiago, } \\
\text { Metropolitan Region }\end{array}$ & Inside apartment & July-August 2009 & 3 & Allison Fernández ${ }^{\mathrm{a}}$ \\
\hline $\begin{array}{l}\text { Pirque, Cordillera, } \\
\text { Metropolitan Region }\end{array}$ & $\begin{array}{l}\text { Sticky trap and visual } \\
\text { observation in alfalfa }\end{array}$ & April 2010 & 2 & Brisy Arancibia ${ }^{\mathrm{a}}$; Audrey Grez \\
\hline $\begin{array}{l}\text { Huechuraba, Santiago, } \\
\text { Metropolitan Region }\end{array}$ & Inside apartment & April 2010 & 9 & Allison Fernández ${ }^{\mathrm{a}}$ \\
\hline $\begin{array}{l}\text { La Pintana, Santiago, } \\
\text { Metropolitan Region }\end{array}$ & $\begin{array}{l}\text { On tree trunks, mainly } \\
\text { Populus sp. }\end{array}$ & May 2010 & 181 & $\begin{array}{l}\text { Elizabeth Gazzano }^{\mathrm{d}} \text {, Brisy } \\
\text { Arancibia }^{\mathrm{a}}, \text { Audrey Grez } \\
\text { Gabriela Lankin }^{\mathrm{c}}\end{array}$ \\
\hline $\begin{array}{l}\text { Huechuraba, Santiago, } \\
\text { Metropolitan Region }\end{array}$ & Inside apartments & May 2010 & 669 & Allison Fernández ${ }^{\mathrm{a}}$ \\
\hline $\begin{array}{l}\text { Colina, Chacabuco, } \\
\text { Metropolitan Region }\end{array}$ & $\begin{array}{l}\text { While mowing the } \\
\text { lawn }\end{array}$ & May 2010 & 9 & Sergio Rothmann ${ }^{\mathrm{b}}$ \\
\hline $\begin{array}{l}\text { Providencia and La } \\
\text { Dehesa, Santiago, } \\
\text { Metropolitan Region }\end{array}$ & $\begin{array}{l}\text { Inside house and } \\
\text { apartment }\end{array}$ & May 2010 & 4 & nn, Gabriela Lankin ${ }^{c}$ \\
\hline $\begin{array}{l}\text { Huechuraba, Santiago, } \\
\text { Metropolitan Region }\end{array}$ & Inside apartments & June 2010 & 219 & Allison Fernández \\
\hline $\begin{array}{l}\text { La Pintana, Santiago, } \\
\text { Metropolitan Region }\end{array}$ & On Populus trunks & June 2010 & 22 & Elizabeth Gazzano $^{d}$ \\
\hline $\begin{array}{l}\text { Nuñoa, Santiago, } \\
\text { Metropolitan Region }\end{array}$ & Apartment window & June 2010 & 9 & Daniel Tapia ${ }^{\mathrm{e}}$ \\
\hline $\begin{array}{l}\text { Puente Alto, Cordillera, } \\
\text { Metropolitan Region }\end{array}$ & Apartment window & June 2010 & 1 & $\mathrm{nn}$ \\
\hline $\begin{array}{l}\text { La Reina, Metropolitan } \\
\text { Region }\end{array}$ & On tree trunks & June 2010 & 3 & Constanza Torres $^{\mathrm{a}}$ \\
\hline
\end{tabular}

nn: name of collector unavailable.

aUndergraduate student, Universidad de Chile.

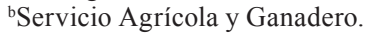

'Academic, Universidad de Chile.

dTechnical assistant, Universidad de Chile.

${ }^{\mathrm{e}}$ Graduate student, Universidad de Chile. 


\section{Resumen}

A. Grez, T. Zaviezo, G. González y S. Rothmann. 2010. Harmonia axyridis en Chile: una nueva amenaza. Cien. Inv. Agr. 37(3): 145-149. En esta nota se documenta la presencia de Harmonia axyridis en Chile, un especie de coccinélido invasiva que ha provocado efectos negativos en otras regiones del mundo, como impactos en otros artrópodos, invasión a hogares y daño en fruta. La especie ha sido encontrada en los últimos tres años en la Región de Valparaíso y Metropolitana, tanto en cultivos, plantaciones como en interior de domicilios. Se advierte de las consecuencias de la introducción de esta especie a Chile y se hace un llamado a tomar medidas, para evitar que esta especie se siga propagando en Chile.

Palabras clave: invasiones biológicas, Coccinellidae, Harmonia axyridis, chinita Asiática o Arlequín.

\section{References}

Almeida, L.M. de, and V.B. da Silva. 2002. First record of Harmonia axyridis (Pallas) (Coleoptera, Coccinellidae): a lady beetle native to the $\mathrm{Pa}$ laearctic region. Revista Brasileira de Zoologia 19: 941-944.

Brown, M.W. 2003. Intraguild responses of aphid predators on apple to the invasion of an exotic species, Harmonia axyridis. BioControl 48: 141153.

Burgio, G., F. Santi, and S. Maini. 2002. On intraguild predation and cannibalism in Harmonia axyridis (Pallas) and Adalia bipunctata L. (Coleoptera: Coccinellidae). Biological Control 24: 110-116.

Cottrell,T.E., and K.V. Yeargan. 1998. Intraguild predation between an introduced lady beetle, Harmonia axyridis (Coleoptera: Coccinellidae), and a native lady beetle, Coleomegilla maculata (Coleoptera: Coccinellidae). Journal of the Kansas Entomological Society 71: 159-163.

Grez A.A., C. Torres, T. Zaviezo, B. Lavandero, and M. Ramírez. 2010. Migration of coccinellids to alfalfa fields varying in adjacent vegetation in central Chile. Ciencia e Investigación Agraria 37(2): 111-121.

Hesler, L.S., R.W. Kieckhefer, and M.A. Catangui. 2004. Surveys and field observations of Harmonia axyridis and other Coccinellidae (Coleoptera) in eastern and central South Dakota. Transactions of the American Entomological Society 130: 113-133.

Huelsman, M.F., J. Kovach, J. Jasinski, C. Young, and B. Eisley. 2002. Multicolored Asian lady beetle
(Harmonia axyridis) as a nuisance pest in households in Ohio. Pages 243-250. In: S.C.Jones, J. Zhai, and W.H. Robinson (eds.). Proceedings of Fourth International Conference on Urban Pests, Blacksburg, Virginia.

Kenis, M., H.E. Roy, R. Zindel, and M.E.N. Majerus. 2008. Current and potential management strategies against Harmonia axyridis. BioControl 53:235-252.

Koch, R.L. 2003. The multicolored Asian lady beetle, Harmonia axyridis: A review of its biology, uses in biological control and non-target impacts. Journal of Insect Science 3: 1-16. Available online at: http://www.insectscience.org/3.32 (Website accessed: December 17, 2009).

Koch R.L., and T.L. Galvan. 2008. Bad side of a good beetle: the North American experience with Harmonia axyridis. BioControl 53:23-35.

Koch, R.L., E.C. Burkness, S.J. Wold Burkness, and W.D. Hutchison. 2004. Phytophagous preferences of the multicolored Asian lady beetle (Coleoptera: Coccinellidae) to autumn ripening fruit. Journal of Economic Entomology 97: 539-544.

Koch, R.L., R.C. Venette, and W.D. Hutchison. 2006. Invasions by Harmonia axyridis (Pallas) (Coleoptera: Coccinellidae) in the Western Hemisphere: Implications for South America. Neotropical Entomology 35: 421-434.

Kovach, J. 2004. Impact of the multicolored Asian lady beetle as a pest of fruit and people. American Entomologist 50:165-167.

Lucas, E., I. Gagne, and D. Coderre. 2002. Impact of the arrival of Harmonia axyridis on adults of Coccinella septempuntata and Coleomegilla maculata (Coleoptera: Coccinellidae). European Journal of Entomology 99: 457-463. 
Pell, J.K., J. Baverstock, H.E. Roy, R.L. Ware, and M.E.N. Majerus. 2008. Intraguild predation involving Harmonia axyridis: a review of current knowledge and future perspectives. BioControl 53:147-168.

Pimentel, D., L. Lach, R. Zúñiga, and D. Morrison. 2000. Environmental and economic costs of nonindigenous species in the United States. BioScience 50:53-65.

Roy, H., and E. Wajnberg. 2008. From biological control to invasion: the ladybird Harmonia axyridis as a model species. BioControl 53: 1-4.

Sala, O.E., F.S. Chapin, J.J. Armesto, E. Berlow, J. Bloomfield, R. Dirzo, E. Huber-Sanwald, L.F. Huenneke, R.B. Jackson, A. Kinzig, R. Leemans, D.M. Lodge, H.A. Mooney, M. Oesterheld, N.L. Poff, M.T. Sykes, B.H. Walker, M. Walker, and D.H. Wall. 2000. Global biodiversity scenarios for the year 2100. Science 287: 1770-1774.

Saini, E.D. 2004. Presencia de Harmonia axyridis (Pallas) (Coleoptera: Coccinelidae) en la provin- cia de Buenos Aires. Aspectos biológicos y morfológicos. RIA 33: 151-160.

Silvie, P., H.P. Aberlenc, C. Duverger, J.M. Bérenger, R. Cardozo, and V. Gomez. 2007. Harmonia axyridis no Paraguai e novos predadores identificados no cultivo do algodoeiro. In : X Simposio de Controle Biologico, 30 June - 4 July 2007, Brasilia, Brasil. s.n., 1 p.

van Lenteren, J.C., D. Babendreier, F. Bigler, G. Burgio, H.M.T. Hokkanen, S. Kuske, A.J.M. Loomans, I. Menzler-Hokkanen, P.C.J. van Rijn, M.B. Thomas, M.G. Tommasini6 and Q.-Q. Zeng. 2003. Environmental risk assessment of exotic natural enemies used in inundative biological control. Biocontrol 48: 3-38.

Vitousek, P.M., C.M. Dantonio, L.L. Loope, and R. Westbrooks. 1996. Biological invasions as global environmental change. American Scientist 84: 468-78. 
